\title{
Ipsi- or contralateral? The dilemma of choosing the best ventriculostomy site for shunt implementation after previous EVD placement
}

\author{
Joachim M. K. Oertel ${ }^{1}$ (D) Matthias J. M. Huelser ${ }^{1}$ \\ Received: 16 April 2020 / Accepted: 18 April 2020 / Published online: 2 May 2020 \\ (C) Springer-Verlag GmbH Austria, part of Springer Nature 2020
}

There is a controversial discussion on what site to use for ventricular-peritoneal shunt placement after treatment of hydrocephalus via an extraventricular drain.

It is an almost daily concern, whether to use the same ventricle site in which the EVD had been previously placed or to insert the drain on the contralateral side. Especially in patients with subarachnoid hemorrhage, the progression from acute to chronic hydrocephalus is very frequently observed (about $23 \%$ of patients with SAH present with an acute hydrocephalus and about $18 \%$ require a shunt for the long term treatment of a chronic hydrocephalus) [1, 4-6].

At a first glance different hypotheses supporting an ipsi- or contralateral approach of shunt placement come to mind. It seems plausible that using the ipsilateral site is associated with a higher risk of infectious complications. A bacterial colonization of the drainage tube that constitutes a connection between the intracranial and extracranial environment, as well as of the superficial wound itself may take place. Also the time period between EVD placement and shunt implantation can influence the risk of infection. All this supports a contralateral approach.

On the other hand, however, benefits from using the existing ventriculostomy may be a reduced perioperative bleeding risk as well as a shorter operating time. Two burrholes and two approaches most likely incorporate a twofold higher risk of approach-related complications.

This article is part of the Topical Collection on Vascular Neurosurgery Aneurysm

Joachim M. K. Oertel

oertelj@freenet.de; joachim.oertel@uks.eu

1 Department of Neurosurgery, Saarland University Medical Center and Saarland University, Faculty of Medicine, Homburg/ Saar, Germany
Current data by Ilic et al. published in this edition's Acta Neurochirurgica compares the two approaches by investigating the outcome and complication rate of 164 patients with SAH and secondary acute hydrocephalus that required shunt implantation. One hundred fifteen patients underwent surgery at the ipsilateral site, whereas 49 patients had the implantation on the contralateral side. In this cohort no statistically significant difference concerning infection (5\% ipsilateral vs. $10 \%$ contralateral) and perioperative hemorrhage could be demonstrated (3.5\% ipsilateral vs. $2.0 \%$ contralateral).

Two previously published studies investigated the influence which implantation site was chosen.

Rammos et al. presented data of 80 patients evaluating complications of solely using the ipsilateral implementation site, which showed no shunt-related infection at all. However, antibiotic impregnated catheters for both EVD and shunt were used [8].

In the largest cohort investigating 523 patients with acute hydrocephalus due to either SAH or AV-malformation-related bleeding, $88.7 \%$ of patients underwent shunt conversion ipsilaterally and $11.3 \%$ contralaterally. Again no significant difference concerning the infection rate (ipsilateral $8.5 \%$ vs. contralateral $6.5 \%$ ) was demonstrated. The rate of shunt-related hemorrhage was found to be slightly higher in implantations on the contralateral side $(1.7 \%$ vs $0.0 \%, p=0.006)$. Here also antibiotic impregnated catheters were used for the EVD but not for the shunt systems [3].

In the cohorts by Ilic et al. and Chalouhi et al., the neurosurgeons individually decided on which side to use. One of the most important guiding factors aiding this decision was the appearance and condition of the wound. In cases where the wound appearance was suspicious for infection or delayed healing, the contralateral side was used [3].

The time period between EVD placement and shunt implantation differed considerably in the abovementioned studies. Ilic at al. had the longest time interval of 46/50 days, compared with Rammos et al. with $12.5 / 12.7$ days and 
Chalouhi et al. with a mean of 14.1 days [3, 8]. Before shunt surgery Ilic et al. and Rammos et al. ruled out a colonization of the EVD catheter [8]. This was not done by Chalouhi et al.; however, antibiotic impregnated catheters were used to minimize the risk of bacterial infection [3].

Data on the duration of the procedures is only provided by Ilic et al. There was no significant time difference found (61 $\mathrm{min}$ vs. $64 \mathrm{~min}$ ).

So, conclusively how can the currently available scientific data help us in making a good decision?

So far no advantages or disadvantages outweighing one or the other implantation site could be demonstrated. Both approaches seem to be equally safe. The preoperative exclusion of microbial catheter colonization and/or the use of antibiotic impregnated catheters have shown to be advantageous. Several studies were able to show a positive effect on the use of antibiotic impregnated catheters [7, 9]. Even though, these specific catheters are more costly, it could be shown that the overall expenses were reduced by avoiding secondary infection and associated revision surgery [2]. Obviously, the surgeon should be aware of any suspicious wound conditions and use the contralateral approach in such cases.

Generally, additional randomized, prospective studies would be helpful to enrich our scientific horizon concerning this matter.

\section{References}

1. Altschul D, Hamad MK, Kobets A, Fluss R, Lin C, Boyke AE, Liu J, Thomas R, Unda SR (2020) A retrospective quality analysis of external ventricular drain infection rates following stroke diagnoses and other brain injuries: comparison of emergency room and ICU/OR setting. Cureus 12:e7173. https://doi.org/10.7759/cureus.7173

2. Attenello FJ, Garces-Ambrossi GL, Zaidi HA, Sciubba DM, Jallo GI (2010) Hospital costs associated with shunt infections in patients receiving antibiotic-impregnated shunt catheters versus standard shunt catheters. Neurosurgery 66:284-289; discussion 289. https:// doi.org/10.1227/01.NEU.0000363405.12584.4D

3. Chalouhi N, Whiting A, Anderson EC, Witte S, Zanaty M, Tjoumakaris S, Gonzalez LF, Hasan D, Starke RM, Hann S, Ghobrial GM, Rosenwasser R, Jabbour P (2014) Comparison of techniques for ventriculoperitoneal shunting in 523 patients with subarachnoid hemorrhage. J Neurosurg 121:904-907. https://doi. org/10.3171/2014.6.JNS132638

4. de Oliveira JG, Beck J, Setzer M, Gerlach R, Vatter H, Seifert V, Raabe A (2007) Risk of shunt-dependent hydrocephalus after occlusion of ruptured intracranial aneurysms by surgical clipping or endovascular coiling: a single-institution series and meta-analysis. Neurosurgery 61:924-933; discussion 933-924. https://doi.org/10. 1227/01.neu.0000303188.72425.24

5. Lin CL, Kwan AL, Howng SL (1999) Acute hydrocephalus and chronic hydrocephalus with the need of postoperative shunting after aneurysmal subarachnoid hemorrhage. Kaohsiung J Med Sci 15: $137-145$

6. O'Kelly CJ, Kulkarni AV, Austin PC, Urbach D, Wallace MC (2009) Shunt-dependent hydrocephalus after aneurysmal subarachnoid hemorrhage: incidence, predictors, and revision rates. Clinical article. J Neurosurg 111:1029-1035. https://doi.org/10.3171/2008.9. JNS08881

7. Parker SL, Attenello FJ, Sciubba DM, Garces-Ambrossi GL, Ahn E, Weingart J, Carson B, Jallo GI (2009) Comparison of shunt infection incidence in high-risk subgroups receiving antibiotic-impregnated versus standard shunts. Childs Nerv Syst 25:77-83; discussion 85 . https://doi.org/10.1007/s00381-008-0743-0

8. Rammos S, Klopfenstein J, Augspurger L, Wang H, Wagenbach A, Poston J, Lanzino G (2008) Conversion of external ventricular drains to ventriculoperitoneal shunts after aneurysmal subarachnoid hemorrhage: effects of site and protein/red blood cell counts on shunt infection and malfunction. J Neurosurg 109:1001-1004. https://doi. org/10.3171/JNS.2008.109.12.1001

9. Sciubba DM, Stuart RM, McGirt MJ, Woodworth GF, Samdani A, Carson B, Jallo GI (2005) Effect of antibiotic-impregnated shunt catheters in decreasing the incidence of shunt infection in the treatment of hydrocephalus. J Neurosurg 103:131-136. https://doi.org/ 10.3171/ped.2005.103.2.0131

Publisher's note Springer Nature remains neutral with regard to jurisdictional claims in published maps and institutional affiliations. 